ROCZNIKI HUMANISTYYCZNE

Tom LXVII, zeszyt 6 - 2019

DOI: http://dx.doi.org/10.18290/rh.2019.67.6-7

\title{
ETYCZNY ASPEKT WYPOWIEDZI OCENIAJACCYCH I WARTOŚCIUJĄCYCH POŚWIĘCONYCH SIENKIEWICZOWI I JEGO TWÓRCZOŚCI \\ (NA PODSTAWIE RECENZJI I TEKSTÓW POLEMICZNYCH PUBLIKOWANYCH W „GŁOSIE”)
}

\begin{abstract}
Od pierwszych recenzji aż po dzień dzisiejszy uczeni i pisarze zajmują diametralnie różne postawy wobec Trylogii i Sienkiewicza. [...] krytycy i pisarze skupili swoją uwage głównie na problemie, czy Sienkiewicz to rzeczywiście ,demon, szkodnik i katastrofa naszego rozumu”, czy też jego twórczość wywiera nadal dodatni wpływ na umysły czytelników ${ }^{1}$.
\end{abstract}

Komentarz T. Jodełki zapisany we Wstępie do pracy Trylogia Henryka Sienkiewicza. Studia. Szkice. Polemiki w pełni oddaje istotę jednej z najważniejszych polemik, która rozegrała się w dziejach polskiej kultury umysłowej u progu XX wieku². Przedmiotem sporu zainicjowanego w 1903 roku przez

Dr hab. LeONARDA MARIAK, prof. US - Zakład Historii Języka Polskiego, Instytut Polonistyki, Kulturoznawstwa i Dziennikarstwa US; adres do korespondencji: Uniwersytet Szczeciński, al. Piastów 40b, 71-065 Szczecin; e-mail: leonarda.mariak@usz.edu.pl

${ }^{1}$ T. JodeŁKA, Wstę, w: Trylogia Henryka Sienkiewicza. Studia, szkice, polemiki, wybór i oprac. T. Jodełka, Warszawa: PIW 1962, s. 6, 7.

${ }^{2}$ Zdaniem wielu badaczy (do tego grona zalicza się również autorka niniejszej publikacji) spór o Sienkiewicza jest równie ważny i ciekawy, jak np. polemiki klasyków z romantykami czy pozytywistów z romantykami. Zob. np.: T. HerBICH, Nieszczery ojciec. Spór Brzozowskiego z Sienkiewiczem, online: https://www.teologiapolityczna.pl/tomasz-herbich-nieszczery-ojciecspor-brzozowskiego-Z-sienkiewiczem-tpct-33- [dostęp: 11.07.2018]; M. ŁUCZEWSKI, Sienkiewicz. Ojciecnarodu, online:https://www.teologiapolityczna.pl//michal-luczewski-narod-historia-i-mitwedlug-henryka-sienkiewicza-tpct-33- [dostęp: 10.09.2018]; K. FIOŁEK, Diagnoza obcości. Brzozowskiego krytyka Sienkiewicza jako spór o polska tożsamość, „Poznańskie Studia Polonistyczne”. Seria Literacka 2015, nr 26 (46) 2015, s. 75, online: https://pressto.amu.edu.pl/index. 
literatów i dziennikarzy skupionych wokół warszawskiego „Głosu”, była twórczość Sienkiewicza (zwłaszcza powieści historyczne i obyczajowe), a także kwestie światopoglądowe, dotyczące głównie przywództwa duchowego i artystycznego pisarza, jego pozycji w ówczesnym społeczeństwie, życiu intelektualnym i literackim ${ }^{3}$.

Od chwili ukazania się w 10. numerze „Głosu” z 1903 roku pierwszego tekstu polemicznego Stanisława Brzozowskiego pt. I smutek tego wszystkiego... krąg krytyków podzielił się na dwa skrajne obozy - entuzjastów, apologetów pisarza i jego twórczości oraz zaciekłych oponentów, którzy nie przebierając w środkach, za wszelką cenę starali się zdyskredytować Sienkiewicza i jego dorobek pisarski. Materialnym świadectwem tych dysput były liczne publikacje zamieszczane na łamach różnych czasopism, zwykle niespecjalistycznych, ale ówcześnie bardzo poczytnych, przeznaczonych dla przeciętnego inteligenta, takich jak np. „Słowo”, „Gazeta Polska” czy „Kurier Warszawski" , a zwłaszcza "Głos”, który tę polemikę zainicjował.

Celem tego artykułu będzie analiza wypowiedzi oceniających i wartościujących, ze względu na ich aspekt etyczny, zawartych w recenzjach, felietonach polemicznych, artykułach krytycznych, listach otwartych i innych często niesprecyzowanych pod względem gatunkowym publikacjach, pisanych przez

php/pspsl/article/view/5067 [dostęp: 20.10.2018]. Słuszność tej tezy zdaje się potwierdzać stała, trwająca dziesiątki lat, ale nadal żywa obecność „sporów” wokół Sienkiewicza i jego spuścizny w krytycznych dyskursach o różnym charakterze: tożsamościowym, estetycznym, genologicznym... oraz olbrzymia - liczona w tysiące - i stale powiększająca się lista pozycji bibliograficznych.

3 Źródłem konfliktu była odpowiedź Sienkiewicza na ankietę „Kuriera Teatralnego” „W sprawie repertuaru pesymistyczno-zmysłowego”, czyli sztuk teatralnych reprezentujących nowy prąd literacki (tu głównie dramatopisarstwo modernistyczne Stanisława Przybyszewskiego). Krytyczna, nieco ironiczno-lekceważąca opinia Sienkiewicza zapoczątkowała pierwszą $\mathrm{z}$ całej serii XX-wiecznych polemik na jego temat. W kontekście prowadzonych tu rozważań warto tę opinię przytoczyć: „Ruja pojawia się tylko w pewnych porach roku i nie wypełnia całkowitego życia, nawet zwierzęcego, tem bardziej więc nie może wypełnić ludzkiego. Z tego względu kierunek, oparty wyłącznie na porubstwie, jest nie tylko szkodliwy etycznie, ale, jako niezgodny z prawdą i naturą rzeczy, wydaje mi się w znaczeniu estetycznem naciąganym, nieszczerym, zatem bezwartościowym" (H. SIENKIEwICZ, Pisma zapomniane i niewydane. Z polecenia rodziny wydat Ignacy Chrzanowski, Lwów-Warszawa-Kraków: Wydawnictwo Zakładu Narodowego im. Ossolińskich 1922, s. 497). Przedstawiciele nowego prądu poczuli się urażeni negatywną oceną Sienkiewicza, a zwłaszcza słowami „ruja” i „porubstwo” - wyraźnie deprecjonującymi wartość młodopolskiej sztuki. W odpowiedzi na wystąpienie Sienkiewicza Stanisław Brzozowski przedstawił w „Głosie” swoją ripostę: ,,[...] wystąpienie Sienkiewicza przybrało formę tak niegodna jego samego, tak nierycerską, nieartystyczną. [...] rzucanie w twarz całemu kierunkowi, całemu pokoleniu obelgi jest rzeczą ciasnej głowy, złej woli albo zaślepienia, rzeczą złego smaku” („Głos” 1903, nr 10, s. 149).

${ }^{4}$ Znacznie bardziej rozbudowaną listę tytułów prasowych podaje T. JODEŁKA w Trylogii Henryka Sienkiewicza, s. 581-584 (źródła tekstów). 
dziennikarzy, literatów, krytyków skupionych wokół tygodnika „Głos”, bezpośrednio zaangażowanych w „spór o Sienkiewicza”.

Kampania antysienkiewiczowska z 1903 roku, jako jedno z najważniejszych zjawisk ówczesnej krytyki była wielokrotnie przedmiotem badań literaturoznawców, nigdy językoznawców. Na temat jej przebiegu, wymowy ideologicznej, konsekwencji napisano wiele ${ }^{5}$, w przeciwieństwie do materii językowej, która do tej pory nie była przedmiotem refleksji naukowej. Niniejszy artykuł będzie więc pierwszym tekstem, w którym przedmiotem badań jest język a zwłaszcza nieetyczne zachowania słowne. W ekscerpcji materiału wzięto pod uwagę wszystkie publikacje krytyczne poświęcone Sienkiewiczowi i/lub jego twórczości, które ukazały się w tygodniku „Głos” ${ }^{\circ}$ w 1903 roku, pióra: Stanisława Brzozowskiego $^{7}$, Wacława Nałkowskiego, Stanisława Kucharskiego, Lucjana Konarskiego, Alfreda Węglińskiego, Jana Władysława Dawida, Stanisława Przybyszewskiego, Aurelego Drogoszewskiego, Grzegorza Glasa (Avanti), Antoniego Millera oraz autorów anonimowych podpisujących się inicjałami et; W.O.

Ze względu na ekstensywność problemu i bogactwo zjawisk językowych analizę materiału ograniczam tylko do wypowiedzi o ujemnej ewaluacji, bezpośrednio lub pośrednio deprecjonujących Sienkiewicza i wartość jego sztuki pisarskiej.

Recenzje $^{8}$ i inne teksty polemiczne o intencji nakłaniająco-wartościującej w sposób szczególny narażone są na nadużywanie języka i naruszenie

${ }^{5}$ K. FIOŁEK, Diagnoza obcości. Brzozowskiego krytyka Sienkiewicza, s. 73-74 (tu zob. bibliografię); B. MAKOWSKI, Aksjologiczna interpretacja literatury w krytyce Stanistawa Brzozowskiego, w: W kręgu etyki, poetyki i dydaktyki stowa, red. T. Patrzałek, Wrocław: Wydawnictwo Uniwersytetu Wrocławskiego 1998.

${ }^{6}$ Pismo było wydawane w Warszawie w latach 1886-1905 (od 1900 roku z podtytułem Tygodnik Naukowo-Literacki, Społeczny i Polityczny). Gazeta sporo miejsca poświęcała publicystyce społeczno-politycznej i naukowo-filozoficznej, popularnością cieszył się stały felieton Bez obłudy i Głosy oraz kroniki Z kraju i Z obcego świata. „Głos” był początkowo pismem postępowym o tendencjach lewicowych, potem zmienił opcję na narodowo-demokratyczną. W dziale literackim publikowali m.in. M. Konopnicka, E. Orzeszkowa, W. Reymont, S. Żeromski, J. Kasprowicz. Znaczące miejsce zajmowała popularyzacja ważnych dzieł literatury obcej. Po 1900 roku w publicystyce dominowały wypowiedzi S. Brzozowskiego i innych przedstawicieli nowego prądu literackiego.

${ }^{7}$ Zob. dołączony do artykułu wykaz analizowanych w artykule tytułów publikacji i ich autorów. W ekscerpcji materiału korzystałam ze zdygitalizowanego wydania „Głosu” udostępnionego przez Mazowiecką Bibliotekę Cyfrową; online: http://mbc.cyfrowemazowsze.pl/dlibra/ publication $\mathrm{id}=19882 \&$ from $=\&$ dirids $=1 \& \mathrm{tab}=1 \& \mathrm{lp}=1 \& \mathrm{QI}=$ [dostęp: 10.11.2018].

8 „U progu XX wieku najpopularniejszą odmianą wypowiedzi krytycznej była recenzja. Opierała się ona na mniej lub bardziej sproblematyzowanym streszczeniu utworu [...]. Streszczenie łączyło się zwykle, w wypadku recenzji utworów epickich, z charakterystyką postaci i przeplatane było sądami wartościującymi. Oceniano wymowę ideową i moralną dzieła, prawdę historyczną, prawdopodobieństwo psychologiczne i obyczajowe, konstrukcję fabuły, charakter i obrazowość opisów, czasami również język i styl. W zależności od rodzaju recenzji, jej rozmiarów i przezna- 
zasad etyki słowa. Dotyczy to zwłaszcza opinii krytycznych o ujemnej ewaluacji, to w nich stosunek nadawcy do opisywanego zjawiska przyjmuje często formę ironii, pogardy, politowania, lekceważenia, czyli uczuć, emocji, postaw sygnalizujących brak szacunku zarówno wobec ocenianego obiektu, jak i odbiorcy recenzji ${ }^{9}$.

Radykalizm $^{10}$, dynamizm antysienkiewiczowskiej kampanii z 1903 roku oraz bezkompromisowa, bardzo zaangażowana postawa jej krytyków miały znaczący wpływ na kształt językowy i treść zamieszczanych w tygodniku artykułów polemicznych oraz na ich etyczny aspekt. Przegląd zebranego materiału wskazuje, że autorzy każdej z analizowanych tu publikacji w mniejszym lub większym zakresie przekraczali granice zachowań etycznych. Warto jednak w tym miejscu podkreślić, że nieetyczne zachowania słowne były cechą charakterystyczną nie tylko środowiska skupionego wokół „Głosu”, ale całej pozytywistycznej krytyki, która do obiektywnych, konstruktywnych i etycznych nie należała. Zdaniem Tomasza Jodełki ma to związek z metodą pracy ówczesnych krytyków, którzy w swoich działaniach „wychodzili od siebie”, nie od dzieła, a to oznacza, że swoje opinie, oceny opierali głównie „1. na własnym doświadczeniu życiowym czy własnej wiedzy historycznej oraz 2 . na własnym odczuciu estetycznym i światopoglądzie"l1. W kontekście zasad etyki słowa przyjęcie takiej perspektywy oceniającej uniemożliwia odróżnianie i oddzielanie informacji od opinii, otwiera drogę dla manipulacji językowej, czyli celowego mylącego opiniowania, a w konsek-

czenia stopień szczegółowości uwag krytycznych bywał rozmaity, zmieniały się też wzajemne proporcje, w jakich pozostawały do siebie streszczenie, interpretacja i wartościowanie. W omawianym tu okresie wykształciło się wiele odmian recenzji, niektóre z nich zbliżały się swym charakterem do wypowiedzi naukowej, większość jednak miała cechy typowe dla rozmaitych form publicystyki. Zdarzały się również recenzje wykorzystujące środki artystyczno-literackie. Inną formą pośrednią były omówienia kilku utworów jednego pisarza, łączące cechy recenzji i portretu literackiego" (za: Słownik literatury polskiej XIX wieku, red. J. Bachórz, A. Kowalczykowa, Wrocław-Warszawa- Kraków: Ossolineum 1991, s. 458; hasło: Krytyka literacka, oprac. M. Gumkowski).

${ }^{9}$ Zob. D. ZDUNKIEWICZ-JEDYNAK, Wyktady ze stylistyki, Warszawa: Wydawnictwo Naukowe PWN 2008, s. 199.

${ }^{10}$ Spory o Sienkiewicza i jego twórczość nie zawsze miały charakter tylko utarczek słownych. W 16. numerze „Głosu” z 1903 roku został opisany przypadek przemocy fizycznej, której dopuścił się zagorzały zwolennik Sienkiewicza na swoim adwersarzu: „Wreszcie ostatnio wywiązała się polemika o społeczne stanowisko Sienkiewicza. [...]. Wówczas chcąc nas zmusić do milczenia [...] uciekł się «Kurjer Warszawski» do jedynego argumentu [...] - gwałtu fizycznego. I oto p. Rabski, przedstawiciel tego „Kurjera” w miejscu publicznem napadł na mnie, jako literackiego kierownika «Głosu». Na napaść odpowiedziałem już połamaniem kija na głowie p. Rabskiego” (J.W. DAWID, Pan Rabski „polemizuje”, „Głos” 1903, nr 16, s. 247).

11 T. JodeŁKA, Wstę, w: Trylogia Henryka Sienkiewicza, s. 10. 
wencji może prowadzić do niezachowania prymatu prawdy jako podstawowego aksjomatu etyki mówienia ${ }^{12}$.

Przechodząc do analizy zebranego materiału przyjmuję za Jadwigą Puzyniną i Dorotą Zdunkiewicz-Jedynak, że nieetyczne zachowania słowne to te, które pogwałcaja fundamentalne dla ludzi prawo do godności ${ }^{13}$. W przypadku badanych tu tekstów założenie to ma charakter arbitralny, ponieważ współczesny badacz nie dysponuje żadnymi opracowaniami teoretycznymi, które stanowiłyby wiarygodną wykładnię wyjaśniająca kwestie etycznych / nieetycznych zachowań słownych, właściwych sferze krytyki literackiej w tamtym czasie. Przesłanką pozwalającą przyjąć to założenie były zamieszczane w różnych źródłach pojedyncze, często lapidarne spostrzeżenia, refleksje na temat etyki, w których kwestia godności człowieka uznawana była jako wartość podstawowa. Spośród sporego grona aktywnych ówcześnie recenzentów tylko Stanisław Brzozowski przedstawił swój punkt widzenia na etyczność w krytyce literackiej:

Etyka jest, zdaniem moim, podstawową nauką całej dziedziny nauk duchowych i kulturalnych. Specjalnie zaś wszystkie zagadnienia estetyki i krytyki są analizy pewną niezmiernie ciekawą postacią zagadnień etycznych. Powiedziałbym, że w zagadnieniach kompozycji właściwie artystycznej, bardziej ogólnie mówiąc, w twórczości wypowiada się najsubtelniej i najściślej nasza istota moralna ${ }^{14}$.

Pewne ogólne stwierdzenia w kwestii zasad poprawnej, etycznej krytyki możemy znaleźć w pojedynczych zapisach kształtującego się dopiero u schyłku XIX wieku kodeksu etyki zawodu dziennikarza ${ }^{15}$ oraz w Stylistyce polskiej Piotra Chmielowskiego, który w podrozdziale Oceny krytyczne zapisał:

W ocenie dzieł piękna nie może chodzić o prawdę niewątpliwą, lecz o prawdopodobieństwo. Norm wedle których moglibyśmy oceniać piękno, dotychczas nie

\footnotetext{
12 Zob. T. PAtrZAŁeK, W kręgu etyki mówienia, w: W kręgu etyki, poetyki i dydaktyki stowa, s. 163.

13 J. PUZYNINA, Mowa nienawiści - a etyka stowa ZES, online: http://www.etykaslowa. edu.pl/wp-content/uploads/2016/05/Mowa-nienawi \%C5\%9Bci-a-etyka-s\%C5\%82owa.pdf [dostęp: 23.10.2018]; J. PUZYNINA, Język wartości, Warszawa 1992; D. ZdUNKIEWICZ-JEDYNAK, Wyktady ze stylistyki, s. 192-202; D. ZDUNKIEWICZ-JEDYNAK, Zachowania komunikacyjne nieetyczne (w poszukiwaniu kryteriów językowych), w: Donum amicitiae. Księga jubileuszowa ofiarowana Pani Profesor Ewie Kołodziejek, red. J. Ignatowicz-Skowrońska, R. Sidorowicz, Szczecin: Volumina.pl 2016, s. 281-292.

${ }^{14}$ S. BRzozowsKI, Kilka stów z teorii powieści, w: Eseje i studia o literaturze, t. 1, wybór i oprac. H. Markiewicz, Wrocław: Zakład Narodowy im. Ossolińskich 1990, s. 379. We wszystkich przywołanych cytatach została zachowana oryginalna ortografia i interpunkcja zapisu.

${ }^{15}$ Zob. W. PISAREK, Kodeksy etyki dziennikarskiej, w: Dziennikarstwo i świat mediów, red. Z. Bauer, E. Chudziński, Kraków: Universitas 2008, s. 557-569; S. ZAKRZEWSKI, Etyka dzien-
} 
odkryto. [...] Cechą krytyki artystycznej powinna być jej przedmiotowość, a krytyk nie powinien uwydatniać swoich czysto osobistych zamiłowań, [...] lecz jeżeli zdoła przenieść się duchowo na stanowisko przez artystę zajęte ${ }^{16}$.

W kwestii „idei osób krytykowanych” wypowiedział się także A. Węgliński - jeden z redaktorów „Głosu” i autor artykułu Zbudźmy się!:

Otóż my z „Głosu” możemy z dumą o sobie powiedzieć, że: 1. Nigdy nie tykamy spraw osobistych ludzi, których działalność publiczną lub literacką krytykujemy; 2. Występując w imię naszych idei, nie unosimy się żadnemi osobistemi względami (18, s. 278).

Mając na uwadze przywołane wyżej uniwersalne kryterium nieetyczności zachowań słownych, w zakres badań włączyłam wypowiedzi wyrażające tylko negatywne emocje, uczucia, których celem było zelżenie, wykpienie, wyszydzenie, wyśmianie lub ośmieszenie Sienkiewicza, jego pisarstwa, a także osób podzielających jego poglądy. Analiza zebranego materiału ujawniła, że zbiór wykładników językowo-tekstowych ${ }^{17}$ wskazujących na złamanie przez krytyków „Głosu” zasad etyki słowa składa się przede wszystkim ze zróżnicowanej

nikarska - wczoraj i dziś, w: Polubić dziennikarstwo, red. S. Zakrzewski, Poznań: Wyższa Szkoła Nauk Humanistycznych i Dziennikarstwa 2009, s. 87.

16 P. CHMIELOWSKI, Stylistyka polska wraz z nauka kompozycji pisarskiej, Warszawa: Nakład Gebethnera i Wolffa 1903, s. 369, 370, online https://polona.pl/item/ stylistyka-polskawraz-z-nauka-kompozycji-pisarskiej,NzA2MDg3/191/\#info: metadata [dostęp: 25.10.2018]. Interesująco przedstawia się również kwestia definiowania i rejestracji hasła etyka w leksykonach polszczyzny ogólnej na przestrzeni wieków. Wyraz nie jest notowany w SStp, SPXVI. (Wprawdzie w ostatnim źródle „etyka” pojawia się, ale tylko jako składnik definicji hasłowej wyrazów „epikureizm”, „filozofia”). Co ciekawe, hasła „etyka” nie znajdziemy w SL, mimo że poświadcza je Kartoteka Stownika polszczyzny XVII i 1. połowy XVIII wieku. Na fiszce nieopracowanego jeszcze hasła został umieszczony cytat dokumentujący z Oekonomiki Aristotelesowey... ksiegi dwoje Sebastiana Petrycego, który w transliteracji ma postać: „Pierwsza jest Ethyka, to jest umiejętność obyczajow przez ktore każdy człowiek ma sam siobie (!) rządzić, y do nawyższego błogosławieństwa dostania przysposabiać. O tey w dziesiąci księgach według Aristotelesowego postępku mamy" (Kraków 1618, s. 44). Późniejsze słowniki rejestrują, oprócz podstawowego hasła „etyka”, także formy pochodne: „etyk, etyczny, etyczność” itp. SW: '1. fil. nauka o moralności, o obyczajach; umiejętność cnoty; nauka o cnotach i obowiązkach. Por. X Deontologja. 2. zbiór przepisów o cnotach i obowiązkach, 3. bł. zam. moralność, obyczajność (SW t. 1, s. 703-704); SJPD: 'ogół zasad, norm postępowania obowiązujących w danej zbiorowości; moralność, nauka o moralności, filozofia moralności' (SJPD, online: http://www.sjpd.pwn.pl/ haslo/etyka/ [dostęp: 05.11.2018]. Opisowość i szczegółowość w definiowaniu hasła może dowodzić (pośrednio) wzrostu zainteresowania społecznego i naukowego zagadnieniami etycznymi. W żadnym z uwzględnionych słowników nie pojawiło pojęcie etyka słowa.

${ }^{17}$ Wybór i klasyfikację cech językowych i tekstowych wskazujących na nieprzestrzeganie reguł etyki przyjmuję za: D. ZDUNKIEWICZ-JEDYNAK, Zachowania komunikacyjne nieetyczne, s. 285-291. 
pod względem formy i funkcji leksyki ekspresywno-wartościującej o ujemnej ewaluacji oraz odpowiednio dobranych treści.

Wśród eksponentów językowych można wskazać ekspresywa (implicytne i eksplicytne) będące nośnikami takich uczuć, jak: lekceważenie, pogarda, obraza. Najczęściej obiektem drwin, kpiny, poniżenia był Sienkiewicz, jego twórczość oraz grono adherentów.

1. Leksyka nazywająca Sienkiewicza:

abiologiczno-asocjalny/dekadencki typ nerwowca: Pan Sienkiewicz należy mianowicie do pewnego typu nerwowców, który w mej klasyfikacji nazwałem kiedyś abiologiczno-asocjalnym albo dekadenckim ${ }^{18}$ (WN1, 43, 679) ${ }^{19}$; apoplektycznie uprzywilejowana osoba: stapanie na palcach wobec majestatu apoplektycznie uprzywilejowanej osoby (GGA2, 15, 235); fatszywy pótbóg (LK, 17, 262); filister (AW, 18, 279); Jowisz, co cisnat grom na głowy Młodych (AW, 18, 278); Mistrz-Jowisz (AW, 18, 279); nieomylny bożek: jednakowo korne względem nieomylnego bożka uwielbienie (SB2a, 14, 221); pan $i$ władca: ludzie dumni $\mathrm{z}$ kwiatka w butonierce, uszczkniętego $\mathrm{z}$ jubileuszowych laurów swego pana i władcy (GGA2, 15, 235); typ ten: typ ten, nie znajdując oparcia, osi życiowej, ani w sobie, w swej fizycznej energii, [...] szuka zwykle takiego oparcia w sztuce (WN1, 43, 679); uprawnione bożyszcze europejskiej burżuazji (LK, 17, 262); wielki arcykaptan (LK, 17, 262); wielki hypnotyzer (!) (AW, 18, 279), wytrawny opowiadacz (SB2d, 18, 288).

2. Leksyka nazywająca adherentów Sienkiewicza:

„,biały gołabek” p. Józefat Nowiński, ekspert etyki płciowej (WN2, 13, 199); histeryczki: Na pisarzy, którzy przyłączyli się do głosu p. Brzozowskiego [...] wylano całemi stagwiami plotki kłamliwe, obnoszone po Warszawie przez histeryczki. (GGA1, 17, 264); literacko-społeczne robactwo (LK, 17, 263); ludzie dumni z kwiatka $w$ butonierce, uszczkniętego z jubileuszowych laurów swego pana i wtadcy (GGA2, 15, 235); szalbierczy augurowie ${ }^{20}$ (LK, 17, 262); apostołowie rozktadu i fatszu (LK, 17, 262); bagno (LK, 17, 262); bardzo biedny człowiek, ostro chory na straszna malarje psychiczna (malaria

$18 \mathrm{~W}$ celu zaoszczędzenia miejsca cytaty podaję tylko przy tych przykładach, których znaczenie bez szerszego kontekstu może być niejasne.

${ }^{19} \mathrm{~W}$ nawiasie podano inicjały autora tekstu, skrót identyfikujący tytułu publikacji, następnie numer pisma i stronę, z której pochodzi cytat.

${ }^{20}$ Augur 'rzymski kapłan, który odczytywał wolę bogów z nieba nad miastem na podstawie zjawisk atmosferycznych i lotu ptaków' (SJPD, online: http://www.sjpd.pwn.pl/haslo/au gur/; dostęp: 30.10.2018). 
psychiczna wg. S. Przybyszewskiego to 'zarazek złości, zajadliwości, nienasyconych pragnień i aspiracji, straszna zaraza ludzi niemocnych') (SP2, 17, 265); eunuchowie taniego oportunizmu: złotodajne żniwo dla wszystkich impotentów myśli i eunuchów taniego oportunizmu (LK, 17, 262); gnijace efemerydy (LK, 17, 262); historyk znakomity, ale duchem parobek 'p. Rabski - zwolennik Sienkiewicza' (GGA1, 17, 265); impotenci myśli: (jw.); kłamliwa i filisterska klika (LK, 17, 262); korupcyjna kamaryla ${ }^{21}$ '(LK, 17, 262); ludzie, którzy dusze swoja pacza, brudza i marnuja (SP2, 17, 265); mętna, bagnista reporteria ${ }^{22}$ (SP2, 17, 266); mottoch (SB2d, 18, 288); poplecznicy: niech poplecznicy Sienkiewicza nie występują w obronie jego w imieniu całego społeczeństwa (KS, 14, 214); pospolitacy słowa 'dziennikarze, zwolennicy Sienkiewicza': Henryk Sienkiewicz nie chciał objąć komendy nad pospolitakami słowa, którzy chcieli stanąć w świetnych blaskach jego imienia (GGA1, 17, 264); społeczno-literacka prostytucja: wam, apostołom rozkładu i fałszu, przystałoby miano społeczno-literackiej prostytucji, która święci ostatnie chwile bezideowych rządów (LK, 17, 262); wielbiciele Sienkiewicza: Późniejsza atmosfera lepkiego brudu, jaką wytworzyli dookoła sporu o prawdę wielbiciele Sienkiewicza, jest dla mnie wstrętnem (GGA1, 17, 264-265); zgraja reporterska (eł, 12, 183).

Zaprezentowane przykłady leksyki ekspresywno-wartościującej, oprócz funkcji stricte nominacyjnej i oceniającej, miały za zadanie obrazić, wykpić Sienkiewicza i jego zwolenników, a w efekcie zdezawuować jego pozycję w opinii czytelników. Nośnikiem braku szacunku w przypadku tej kategorii wykładników są określenia (proste i analityczne), zaczerpnięte z wybranych kręgów tematycznych o odpowiednich konotacjach i proweniencji, np.:

- słownictwo z kręgu tematycznego chorób (psychicznych): histeryczka, malaria psychiczna, apoplektyczny, nerwowiec

- słownictwo kojarzące się z brudem, rozkładem (głównie moralnym): bagno, rozkład, brudzić, gnić, mętny

- słownictwo związane z kłamstwem, brakiem uczciwości: klika, kamaryla, korupcyjny, kłamliwy, szalbierczy

\footnotetext{
21 Kamaryla '1. grupa osób wykorzystująca swoje stanowiska dla własnych korzyści i uprawiania stronniczej polityki; 2. grupa dworzan faworyzowanych przez panującego, wywierająca wpływ na bieg spraw publicznych' (SJPD, online: http://www.sjpd.pwn.pl/haslo/kamar yla/; dostęp: 30.10.2018).

${ }^{22}$ Reporteria 'przestarz. 2. ogół dziennikarzy’ (SJPD, online: http://www.sjpd.pwn.pl/ha slo/reporteria/; dostęp: 30.10.2018).
} 
- metafory odzwierzęce, metafory o funkcji reifikującej: anamorfoza, efemeryda, robactwo

- wyrazy, które mają wpisany w strukturę sem znaczeniowy 'gorszy, pozbawiony wartości’: parobek, pospolitak, motłoch, poplecznik

- słownictwo związane ze sferą życia seksualnego, wyrazy naruszające tabu językowe: eunuch, etyka ptciowa, impotent, prostytucja.

Lucjan Konarski - mniej znany, ale niezwykle zawzięty przeciwnik Sienkiewicza w artykule pt. Bez masek umieścił cały zbiór określeń pogardliwych, wyszydzających osoby podzielające światopogląd i system wartości autora Trylogii:

Wszyscy mizerni felietoniści, udajacy poważnych publicystów, kapłani-plagjatorzy, faryzeusze z teatru Nowości, demagodzy-fabrykanci, altruistyczni lichwiarze, idjotyczni krytycy, nędzarze-bankierzy, próżniacy-prezesi, cnotliwi rozpustnicy, dobroczynni kapitaliści, uczeni blagierzy, sprzedajni redaktorzy, błazeńscy poeci, działacze-synekurzyści $i^{23}$, kabotyńscy literaci, wszyscy ci wyzuci z odrobiny idei ludzie, cate in gremio szarlatańskie café-chantant wspótczesnych przedstawicieli myśli $i$ czynu, całe to sprzymierzone bagno egoizmu, obłudy, reporterji i szarzyzny zawrzało nagła obawą (LK, 17, 261).

Kumulacja negatywnych emocji i ocen zawartych w tym cytacie wynika nie tylko z hiperbolizacji wyliczenia określeń, ale także z ich struktury większość nazw ma postać wyrażeń lub apozycji oksymoronicznych. Oparte na antylogii nominacje typu: nędzarz-bankier, błazeński poeta, cnotliwy rozpustnik nadają całej wypowiedzi ironiczny charakter i uwydatniają dystans autora tekstu wobec opisywanych osób. Można je uznać za klasyczny przykład wypowiedzi, której intencją był atak przez poniżenie ${ }^{24}$.

W przypadku określeń Sienkiewicza dominuje leksyka, której celem wbrew znaczeniu dosłownemu - miało być podważanie autorytetu Sienkiewicza w kręgach artystyczno-literackich i jego pozycji w życiu społecznym. Deprecjacji i ośmieszeniu ,wielkości” autora Trylogii służą głównie zabarwione ironią nazwy-etykiety, takie jak: bóg, pótbóg, Jowisz, a także ekplicytnie pogardliwe bożek, bożyszcze. Drwina i szyderstwo ukryte pod pozorami aprobaty i pozytywnego wartościowania stanowią źródło swoistej „,desakralizacji”, która wprawdzie pośrednio, ale jednoznacznie wskazywała czytelnikom jak powinni traktować i oceniać Sienkiewicza.

\footnotetext{
${ }^{23}$ Synekurzysta 'osoba korzystająca z synekury, czyli dobrze płatnego stanowiska, niewymagającego wiele wysiłku ani umiejętności’ (SJPD, online: http://www.sjpd.pwn.pl/haslo/syne kurzysta/; dostęp: 30.10.2018).

${ }^{24}$ D. ZDUNKIEWICZ-JEDYNAK, Zachowania komunikacyjne nieetyczne, s. 282.
} 
Wśród językowych eksponentów nieetycznych zachowań słownych znalazła się liczna grupa ekspresywno-wartościujących form atrybutywnych o negatywnym ładunku, które bezpośrednio lub pośrednio (za pomocą ironii, metafory) eksplikowały nieżyczliwe, nawet wrogie intencje krytyków „Głosu” wobec Sienkiewicza, jego pisarstwa oraz osób mu życzliwych. Zgromadzony materiał można uporządkować ze względu na intencjonalność uczuciową oraz zakładany efekt w określaniu obiektów:

- pogarda, poniżenie: plugawe słowa (AW, 18, 278); ptytki aforyzm (AW, 18, 278); tani dowcip filistra (AW, 18, 278); próżniaczy thum psychiczny (JWD, 17, 263); ptytki a przemyślny arlekin (LK, 17, 262); mdło-letnia temperatura środowiska duchowego (SB2a, 14, 222); sława fetyszystyczna (SB2a, 14, 221);

- niski poziom moralny i etyczny: zakażony tłum (JWD, 17, 263); czyn nieszlachetny, spróchniały skarbiec reakcji (JWD, 17, 262); dziwna, słaba, ptytka rasa dusz ludzkich (SB2a, 14, 222); mętna, bagnista toń (GGA1, 17, 266); atmosfera lepkiego brudu (GGA1,17, 264-265); typ staby (NW1, 43, 259); typ przesubtelniony, aspoteczny (NW1, 43, 259); brudne cele osobistych zawiści (SP1, 13, 201);

- prymitywizm, praktycyzm, bezideowość: dusze poziome, ospate a zabiegliwe (LK, 17, 262); robota pieczeniarska (WN1, 43, 679); uśmiechnięta, rozkochana $w$ sobie płytkość (SB2c, 17, 271);

- niski poziom intelektualny: głupia gęś w spódnicy (LK, 17, 262); mierny mózg (LK, 17, 262); bezmózgie [kobiety] (O.W., 15, 232); umysł dyletancki (WN1, 43, 679); ciasna głowa (SB3, 10, 149); kobieta niewolnicza, głupia (WN1, 43, 679);

- manipulowanie, mówienie nieprawdy: kłamliwa klika (LK, 17; 263); ogtupiajace jednostki (JWD, 17, 263); jezuickie przemilczenia (LK, 17, 262); fatszywa bigoteria (LK, 17, 262); fatszywy patos (LK, 17, 261); plotki kłamliwe (GGA1, 17, 264-265); chcą przekupić (eł, 12, 184);

- małostkowość: filisterska klika (LK, 17, 263).

Jak widać z zaprezentowanych tu przykładów zawarty w nich komponent oceny negatywnej uzewnętrznia uczuciową postawę krytyków. Wśród sygnalizowanych uczuć można wskazać przede wszystkim te, które wyrażają lekceważenie, pogardę i całkowitą dezaprobatę wobec nie tylko samego Sienkiewicza, ale także innych realiów z nim związanych. Ze względu na uogólniony zakres uwag krytycznych powyższe wypowiedzi mogą być uznane za agresywne ${ }^{25}$.

\footnotetext{
25 Zdaniem Tomasza Korpysza przy odróżnieniu uzasadnionej i potrzebnej krytyki od zachowań agresywnych należy wziąć pod uwagę to, co krytyk wziął pod uwagę - konkretne działania osoby i ich efekty, czy krytykę tej osoby poprzez całość podejmowanych przez nią
} 


\section{Leksyka związana ze sferą twórczości Sienkiewicza}

Publicyści „Głosu” w zakres swoich krytycznych refleksji włączali także twórczość Sienkiewicza, zwłaszcza niektóre nośne ideologicznie elementy fabuły powieści historycznych i obyczajowych oraz kreacje bohaterów. Nieetyczność zachowań słownych w tym przypadku ma swoje źródło w mało konstruktywnych, zwykle zabarwionych ironią ocenach i kpiących komentarzach, wyśmiewających dorobek pisarski Sienkiewicza, konkretne utwory, a zwłaszcza wzorce osobowe postaci literackich (w sposób szczególny postacie kobiet). Repertuar środków językowych, które mogą świadczyć o przekroczeniu zasady etyki słowa, jest tu niezwykle zróżnicowany i bogaty. Poniżej przedstawiam wybór najczęściej spotykanych, najbardziej reprezentatywnych, za kryterium klasyfikacji przyjęłam wyróżnik formalny (środki gramatyczne, leksykalne - proste i złożone, a także większe całostki semantyczne), ponieważ pod względem funkcji i znaczenia wszystkie są określeniami obraźliwymi, nieżyczliwymi, służącymi dezawuacji opisywanych obiektów.

1. Środki gramatyczne:

- formy liczby mnogiej męskich nazwisk bohaterów:

Jaremy, Połanieccy, Ursusy (WN1, 34, 679)

2. Środki leksykalne (słownictwo i połączenia wyrazowe ekspresywno-wartościujące o negatywnej ewaluacji):

pisarstwo (ogólnie), proces twórczy: produkcja: Tak więc w produkcji pana Sienkiewicza można odróżnić pierwotny pęd naturalny (WN, 43, 679); bawić się: bawi się on doskonale przeprowadzając swych bohaterów przez najtrudniejsze perypetje (SB2d, 18, 256); nudzić się: Sienkiewicz nudzi się sam pisząc, jakże zdoła zabawić innych (SB2d, 18, 256); brzakadełka: Jeśli dłoń jego nie może zdzierżyć buławy, niechże przynajmniej nie sięga po brząkadełka (SB3, 10, 150); aspołeczny: Zestawiona ze współczesnem życiem społecznem jest twórczość Sienkiewicza bezwzględnie niewspółmierną, jest, powiedzmy prawdziwe słowo aspołeczna (SB2b, 16, 255); robota pieczeniarska: robota pieczeniarska dla zjednania sobie chlebodawców arystokracji, plutokracji i kleru (WN1, 43, 679); sztuczne „dopomaganie sobie”: Tak więc w produkcji pana Sienkiewicza można odróżnić pierwotny pęd naturalny, a następnie sztuczne „dopomaganie sobie” (WN1, 43, 679); stup soli gryzacej

działań. To drugie zachowanie świadczy o agresji werbalnej (T. KoRPYsZ, Naruszanie etyki słowa, online: http://idziemy. pl/porady/jezyk/naruszanie-etyki-slowa; dostęp: 30.10.2018). 
“„Wiry”: dlaczego się tak stało, że powieść [,Wiry”] w dobrej poczęta wierze zmieniła się w słup soli gryzącej (GGA2, 15, 235);

bohaterowie: twory małych uczuć [Sienkiewicza] (WN1, 43, 679); celowo skonstruowane automaty, zbierające dla [Sienkiewicza] pieniądze (WN1, 43, 679); gęś: imię Anielki [główna bohaterka „Wirów”] - psedotypu kobiety polskiej - jest „gęś i nic więcej” (GGA2, 15, 235); psychopatologia sexualis: Dusza Płoszowskiego należy do typu dusz psychopatologia sexualis (SB2d, 18, 288); idylliczny staruszek 'św. Paweł': apostoł Paweł - idylliczny staruszek, który nie ma nic lepszego do roboty niż błogosławić związkowi Winicjusza i Ligii (SB2a, 14, 222); oleodruk, przypominajacy święte obrazki sprzedawane po kramikach pod kościotem 'Paweł z Tarsu': Paweł z Tarsu wyrodził się u Sienkiewicza w oleodruk, przypominający święte obrazki sprzedawane po kramikach pod kościołem (GGA2, 15, 235); wielki bohater starożytności Ursus ${ }^{26}[\ldots]$ obecnie wysubtelniony, pracuje $w$ modernistycznym interesie wody uzdrawiajacej (WN2, 13, 199).

Lektura wszystkich wypowiedzi krytycznych na temat Sienkiewicza opublikowanych w „Głosie” dowodzi, że najwięcej ocen nieżyczliwych, ironicznych, lekceważących dotyczy postaci kobiecych. Przesadne zainteresowanie kreacją kobiet w twórczości Sienkiewicza miało prawdopodobnie dwie przyczyny: 1. prężnie rozwijający się na ziemiach polskich ruch emancypacyjny, który przyniósł zmiany w pozycji społecznej, obyczajowej, towarzyskiej kobiety, oraz 2. wzorzec kobiety propagowany w powieściach obyczajowych, a zwłaszcza historycznych Sienkiewicza, który od wzorca kobiety wyzwolonej odbiegał. Rozbieżność ideologiczno-światopoglądowa sprawiła, że krytycy „Głosu" - reprezentujący środowisko postępowe, popierające emancypację, szczególnie chętnie wykorzystywali te argumenty, aby pod pozorem krytyki bohaterek powieściowych wyśmiać, zdyskredytować w opinii czytelników konserwatywne poglądy Sienkiewicza. Najwięcej zabarwionych ironią, lekceważących opinii na temat postaci kobiecych znajdziemy w podpisanym inicjałami W.O. artykule pt. Protest kobiety, np.: różnoimienne postaci jednego i tego samego typu (O.W., 15, 232); postacie ogarnięte manja (O.W., 15, 232);

\footnotetext{
${ }^{26}$ Na terenie posiadłości w Oblęgorku znajdowało się źródło o nazwie „Ursus”, zawierające wodę mineralną o wysokiej jakości. W 1904 roku zawiązała się spółka, mająca eksploatować i sprzedawać wodę. Zamiar nie został zrealizowany, ponieważ droga z Oblęgorka do Kielc była tak wyboista, że podczas transportu tłukła się połowa butelek. (Zob. Henryk SIENKIEWICZ, Listy, t. 2, cz. 1-3: Jadwiga i Edward Janczewscy, oprac., wstępem i przypisami opatrzyła M. Bokszczanin, Warszawa: PIW 1996; tu przypis 3 do listu nr 479 z 3 września 1902 roku, adresowanego do szwagierki pisarza - Jadwigi z Szetkiewiczów Janczewskiej).
} 
postacie milczace, tajemnicze, piękne jak cień, bez woli, bez charakterów, bez czynu (O.W., 15, 232); niewyraźne, przezroczyste postaci (O.W., 15, 232); kobieta kwiat - nie kobieta-czlowiek (O.W., 15, 232); Kura domestica-Bigielowa, Messalina-Castelka, Kokota-Osnowska, Gęś-Maszkowa (O.W., 15, 232); cień, bez krwi i kości, a tem bardziej bez myśli, i poczucia człowieczeństwa: typowa bohaterka to cień, bez krwi i kości, a tem bardziej bez myśli, i poczucia człowieczeństwa (O.W., 15, 232); kobiety bierne, cicho przesuwają się przez scenę życia (O.W., 15, 232); lalkowate, prawnie poślubione odaliski: Sądząc z powieści Sienkiewicza polki (!) to, jedynie lalkowate, prawnie poślubione odaliski (O.W., 15, 232). W tekstach pozostałych autorów krytyka sienkiewiczowskich bohaterek pojawia się sporadycznie, ale zawsze ma ironiczny wydźwięk: nałożnice, smutny człowiek: Sienkiewicz uczynił z kobiety nałożnicę. Sienkiewicz prześlepił w niej smutnego człowieka (GGA2, 15, 235); ideał Płoszowskiego - kobieta z sercem kokoty i kurzym mózgiem, urobionym $w$ odlewni tradycyjnych ideatów (AM, 13, 200).

Prócz eksponentów leksykalnych czynnikami, które wskazują na złamanie reguł etyki słowa, są wyrażone wprost sądy wartościujące i opinie o ujemnej ewaluacji. Najczęściej w taki sposób polemiści Sienkiewicza piętnowali jego twórczość, zwłaszcza walory estetyczne i światopoglądowe. Poniżej prezentuję jedynie niewielki wybór z bardzo obszernej listy podobnych przykładów, których funkcją było zdyskredytowanie:

twórczości Sienkiewicza:

w twórczości HS wszystko jest jasne, ale nie jest to jasność petna tragicznej mocy [...] jest to jasność $i$ spokój, promienny spokój lekkomyślnego duchowego lenistwa (SB2a, 14, 222); jedyny imperatyw dla chwili obecnej wskazat [Sienkiewicz]: „pewna kobiete”, „ziemie”, „stużbe boża” $i$ „perkaliki” (SB2a, 14, 223); Sienkiewicz dat nam apologje szlachty, apologje pijaństwa, niesforności, warcholstwa (SK, 14, 214); dzieła Sienkiewicza dziełami sztuki się mienia, ale nie ma $w$ nich ani śladu, ani znaku sztuki (SB2d, 18, 288); dzieła S. sa symptomatem i czynnikiem ponizenia duchowego (SB2d, 18, 288); wszędzie zawsze to samo: uwieńczone powodzeniem usiłowanie zbagatelizowania $i$ uproszczenia tego, co głębokie, unikanie wszelkich zawitości psychologicznych (SB2d, 18, 288); Język nigdy go nie zdradza, stowo nie zawiera u niego nigdy poza treścia swa bezpośrednia żadnych perspektyw... Stad zamitowanie do zdań krótkich, wyrażeń najprostszych $w$ rodzaju „bardzo moja" - oto owa cata maniera prostoty (SB2d, 18, 256);

\section{konkretnych utworów:}

Wiary w Quo vadis jest tyle ile prawdy duchowej $w$ trzeciorzednej operze (SB2d, 18, 256); W Krzyżakach znać jest wszakże znużenie, ciekawość stępia- 
ta (SB2d, 18, 256); Z kart Krzyżaków bije przymus, wyczerpanie i znudzenie wewnętrzne (SB2d, 18, 256);

wkładu Sienkiewicza w rozwój literatury polskiej i światowej:

jego sława uzewnętrzniła się tylko w mniej, lub więcej cyrkowych przeróbkach jego dziet, jego dzieła i przeróbki dziet nie maja ani ze sztuka, ani z rozwojem kultury nic wspólnego (SB2d,18; 288); jego rola $w$ artystycznym $i$ kulturalnym rozwoju Europy wspótczesnej jest żadna, niema on $w$ sobie nic, czem mógłby wptynać na rozwój europejskiej sztuki pisania, niema $w$ sobie nic czem mógłby dusze wspótczesnego Europejczyka rozszerzyć $i$ wzbogacić - jak unas, tak i tam bawi ja tylko i rozleniwia (SB2d, 18, 288); mało jest pisarzy, którzyby się $w$ takim stopniu, jak H. Sienkiewicz do pomniejszenia duszy ludzkiej w jej właściwem znaczeniu przyczynili (SB2c, 17, 271).

Wypowiedzi tego typu są najbardziej charakterystyczne dla publikacji S. Brzozowskiego (p. lokalizacja cytatowa), który spośród wszystkich publicystów i literatów czynnie zaangażowanych w kampanię przeciwko Sienkiewiczowi, najwięcej miejsca poświęcił ocenie twórczości autora Trylogii. W kilku dość obszernych publikacjach ${ }^{27}$ (w tym jedna trzyczęściowa) zawarł swój osobisty pogląd na pisarstwo Sienkiewicza oraz jego rolę w ówczesnym życiu społecznym, kulturalnym, duchowym. Zdaniem Tomasza Herbicha: „Brzozowski - co do tego nie ma watpliwości - doceniał swojego przeciwnika i właśnie dlatego, że widział wyraźnie jego siłę i znaczenie, z całych sił chciał pozbawić go wpływu na polską duszę ${ }^{28}$. Prawdopodobnie źródłem zachowań nieetycznych w tekstach Brzozowskiego była właśnie owa determinacja, by - za wszelką cenę, nie przebierając w środkach - pokazać czytelnikom, ile zła polskiej i światowej literaturze oraz społeczeństwu wyrządził Sienkiewicz.

Na zakończenie podjętych tu rozważań warto wspomnieć o innych, mniej powszechnych, przejawach nieetycznych zachowań słownych właściwych antysienkiewiczowskiej krytyce, takich jak np.: nieprzestrzeganie zasad etykiety językowej oraz obniżenie rejestru stylistycznego ${ }^{29}$. W pierwszym przypadku chodzi o świadome pomijanie grzecznościowych form adresatywnych (pan) lub posługiwanie się samym nazwiskiem, $\mathrm{z}$ pominięciem imienia $\mathrm{i}$ formy adresa-

\footnotetext{
${ }^{27} \mathrm{~W}$ przypadku tekstów tego autora trudno jest określić, z jakim gatunkiem (literackim, dziennikarskim) mamy do czynienia. Po częśsi są to recenzje, po części artykuły (krytyczne), felietony lub eseje filozoficzne.

28 T. HeRBICH, Nieszczery ojciec. Spór Brzozowskiego z Sienkiewiczem, online: https: //www.teologiapolityczna.pl/tomasz-herbich-nieszczery-ojciec-spor-brzozowskiego-z-sienkiewi czem-tpct-33- [dostęp: 01.11.2018].

${ }^{29}$ Zob. D. ZDUNKIEWICZ-JEDYNAK, Zachowania komunikacyjne nieetyczne, s. 291.
} 
tywnej, lub tylko inicjałem nazwiska, np.: $S$. dał nam apologję szlachty, apologje pijaństwa (SK, 14, 214); p. S. (WN2, 13, 199); wielbiciele Sienkiewicza (GGA1, 17, 264). Do tej kategorii nieetycznych zachowań słownych można zaliczyć wyrażenie ten typ, którym konsekwentnie posługiwał się W. Nałkowski w swoich publikacjach. Pisząc o Sienkiewiczu jak o zjawisku, a nie o osobie werbalizował swoje lekceważenie i chęć deprecjacji przeciwnika:

typ ten, nie znajdując oparcia, osi życiowej, ani w sobie, w swej fizycznej energii, $[\ldots]$ ani na zewnątrz siebie, $[\ldots]$. Ale wkrótce i ta pobudka zaczyna nie wystarczać; występuje reakcja biologiczna, która u tego typu słabego o umyśle dyletanckim przyjmuje formę religijną i w ogóle tradycyjną (WN1, 43, 679).

W drugim przypadku manifestowanie braku szacunku wobec Sienkiewicza odbywało się poprzez świadome obniżenie oficjalnego (neutralnego) rejestru stylistycznego, właściwego krytyce osób znanych, poważanych, na potoczny - mniej odpowiedni, bo dopuszczający większą poufałość i zmniejszenie dystansu między piszącymi a opisywanym obiektem. Do najczęściej wykorzystywanych wyróżników potoczności świadczących o zmianie stylu, należą:

frazeologizmy: polemika $\mathrm{w}$ pewnych organach prasy warszawskiej traci szynkiem (AW, 18, 278); obrzucaja osobę przeciwnika btotem, pełną ręką (AW, 18, 278); To się wie, to się wam umyślnie powtarza, ażebyście łatwiej mogli przełknać gorzka pigutke (GGA2, 15, 235); pakować jakiemuś idiocie $w$ głowe deklinacje łacińskie (WN1, 43, 679);

zdrobnienia: epoka kramarstwa i drobnych świnstewek; kapitalik tkliwości i rozczulenia, którym oni mierzą wielkość artysty (GGA2, 15, 235); S. jest twórcą takich właśnie potrzebnych idealików i medalików (GGA2, 15, 235); ambicyjka literacka (SP1, 13, 201);

słownictwo pospolite: szlachecki bzik (SK, 14, 214); obrzucają osobę przeciwnika błotem, pełną ręką, wprost z rynsztoka wziętem (AW, 18, 278); on, mniej lub więcej zmizerowany, w watpliwych butach, $z$ wytartymi łokciami; Ach, zamiast tu siedzieć i dukać - być, jak oni (WN1, 43, 679); nie odsądzajcie od czci tych, co się z wami nie solidaryzują $i$ nie przygladajcie się ich majtkom, bo to nieestetyczne i nie ,po petroniuszowsku” (SK, 14, 214).

Nieetyczne zachowania słowne są cechą charakterystyczną wszystkich tekstów krytycznych związanych z kampanią antysienkiewiczowską 1903 roku. Analiza zgromadzonego materiału pokazała, że przekraczanie granic etyki słowa jest 
widoczne zarówno w planie treści, jak i w planie wyrażania. Nieżyczliwe, lekceważące, pogardliwe uwagi krytyków miały zdyskredytować, obrazić, a także wykpić lub ośmieszyć Sienkiewicza i jego zwolenników, podważyć autorytet i ugruntowaną pozycję największego powieściopisarza drugiej połowy XIX wieku. Wśród środków językowych, których obecność wskazuje na złamanie zasad etyki, dominuje zróżnicowana pod względem formy, znaczenia i funkcji leksyka wartościująco-oceniająca o ujemnej ewaluacji. Kontestatorzy kwestionujący wielkość Sienkiewicza i jego twórczości argumenty ad rem zastępowali argumentami ad personam, dlatego ich krytyka jest pozbawiona szacunku, ironiczna i najczęściej oparta na uprzedzeniach. Żadnemu z autorów (nawet Brzozowskiemu czołowemu krytykowi sporu) nie udało się napisać dobrej recenzji krytycznej, obiektywnej, konstruktywnej, pozbawionej osobistych animozji, a przede wszystkim respektującej zasady etyki słowa.

\section{BIBLIOGRAFIA}

BRzozowsKi S.: Kilka słów z teorii powieści, w: Eseje i studia o literaturze, t. 1, wybór i oprac. H. Markiewicz, Wrocław: Zakład Narodowy im. Ossolińskich 1990.

ChMiElowsKi P.: Stylistyka polska wraz z nauką kompozycji pisarskiej, Warszawa: Nakład Gebethnera i Wolffa 1903, online: https://polona.pl/ item/stylistyka-polska-wraz-z-naukakompozycji-pisarskiej,NzA2MDg3/ 191/\#info:metadata.

FIOŁEK K.: Diagnoza obcości. Brzozowskiego krytyka Sienkiewicza jako spór o polską tożsamość, „Poznańskie Studia Polonistyczne”. Seria Literacka 2015, nr 26(46), online: https://pressto.amu.edu.pl/index.php/pspsl/article/view/5067.

HeRBICH T.: Nieszczery ojciec. Spór Brzozowskiego z Sienkiewiczem, online: https://www. teologiapolityczna.pl/tomasz-herbich-nieszczery-ojciec-spor-brzozowskiego-z-sienkiewiczemtpct-33-

KORPYSZ T.: Naruszanie etyki słowa, online: http://idziemy.pl/porady/jezyk/naruszanie-etykislowa

ŁUCZEWSKI M.: Sienkiewicz. Ojciec narodu, online: https://www.teologiapo lityczna.pl//michalluczewski-narod-historia-i-mit-wedlug-henryka-sienkiewicza-tpct-33-

MAKOwSKI B.: Aksjologiczna interpretacja literatury w krytyce Stanisława Brzozowskiego, w: W kręgu etyki, poetyki i dydaktyki słowa, red. T. Patrzałek, Wrocław: Wydawnictwo Uniwersytetu Wrocławskiego 1998.

PATRZAŁEK T.: W kręgu etyki mówienia, w: W kręgu etyki, poetyki i dydaktyki słowa, red. T. Patrzałek, Wrocław: Wydawnictwo Uniwersytetu Wrocławskiego 1998.

PISAREK W.: Kodeksy etyki dziennikarskiej, w: Dziennikarstwo i świat mediów, red. Z. Bauer, E. Chudziński, Kraków: Universitas 2008.

PUZYNINA J.: Język wartości, Warszawa: Wydawnictwo Naukowe PWN 1992.

PUZYNINA J.: Mowa nienawiści - a etyka słowa ZES, online: http://www.etykaslowa.edu. $\mathrm{pl} / \mathrm{wp}$-content/uploads/2016/05/Mowa-nienawi\%C5\%9Bci-a-etyka-s\%C5\% 82owa.pdf.

SIENKIEWICZ H.: Listy, t. 2, cz. 1-3: Jadwiga i Edward Janczewscy, oprac. wstępem i przypisami opatrzyła M. Bokszczanin, Warszawa: PIW 1996. 
SIENKIEWICZ H.: Pisma zapomniane i niewydane. $Z$ polecenia rodziny wydał Ignacy Chrzanowski, Lwów-Warszawa-Kraków: Wydawnictwo Zakładu Narodowego imienia Ossolińskich 1922.

Słownik literatury polskiej XIX wieku, red. J. Bachórz, A. Kowalczykowa, Wrocław-Warszawa-Kraków: Ossolineum 1991.

Trylogia Henryka Sienkiewicza. Studia, szkice, polemiki, wybór i oprac. T. Jodełka, Warszawa: PIW 1962

ZAKRZEWSKI S.: Etyka dziennikarska - wczoraj i dziś, w: Polubić dziennikarstwo, red. S. Zakrzewski, Poznań: Wyższa Szkoła Nauk Humanistycznych i Dziennikarstwa 2009.

ZDUNKIEWICZ-JEDYNAK D.: Wykłady ze stylistyki, Warszawa: Wydawnictwo Naukowe PWN 2008.

ZDUNKIEWICZ-JEDYNAK D.: Zachowania komunikacyjne nieetyczne (w poszukiwaniu kryteriów językowych), w: Donum amicitiae. Księga jubileuszowa ofiarowana Pani Profesor Ewie Kołodziejek, red. J. Ignatowicz-Skowrońska, R. Sidorowicz, Szczecin: Volumina.pl 2016.

\section{SŁOWNIKI}

Słownik staropolski, red. S. Urbańczyk, t. I-X, Wrocław 1953-1987 [SStp].

Słownik języka polskiego, red. A. Karłowicz, J. Kryński, W. Niedźwiedzki, t. I-VIII, Warszawa 1900-1927 [SW].

LINDE S.B.: Słownik języka polskiego, t. I-VI, Lwów 1854-1860 (Wydanie drugie, poprawne i pomnożone) [SL]

Słownik języka polskiego, red. W. Doroszewski, t. I-XI, Warszawa 1958-1969; online: http:// www.sjpd.pwn.pl/ [SJPD].

Kartoteka słownika polszczyzny XVII i 1. połowy XVIII wieku, online: www.orcin.org.pl/pu blication/20029.

\section{BIBLIOGRAFIA MATERIAŁÓW ŹRÓDŁOWYCH}

Avanti (G. Glass): Do porządku!, „Głos” 1903, nr 17, s. 264-265 [GGA1].

Avanti (G. Glass): Jeszcze słowo..., „Głos” 1903, nr 15, s. 235 [GGA2].

BRzozowsKi S.: Czas mówić!, „Głos” 1903, nr 15, s. 230-232 [SB1].

BRZOZOWSKI S.: Henryk Sienkiewicz i jego stanowisko w literaturze współczesnej, „Głos” 1903, nr 14, s. 221-223 [SB2a]; cd „Głos” nr 16, s. 254-256 [SB2b]; cd. „Głos” nr 17, s. 270-271 [SB2c]; cd. „Głos” nr 18, s. 287-289 [SB2d].

BRZOZOWSKI S.: I smutek tego wszystkiego, „Głos” 1903, nr 10, s. 148-150 [SB3].

BRzOzOWSKI S.: Komentarz przez życie napisany, „Głos” 1903, nr 16, s. 248 [SB4]

DAWID J.W.: Pan Rabski „polemizuje”, „Głos” 1903, nr 16, s. 246-247 [JWD].

DROGOSZEWSKI A.: O „obcym człowieku”, „Głos” 1903, nr 16, s. 247-248 [AD].

eł, Etyka „czystych rąk”, „Głos” 1903, nr 12, s. 183-184 [E].

KonARSKI L.: Bez masek, „Głos” 1903, nr 17, s. 261-263 [LK].

KUCHARSKI S.: Jak Sienkiewicz „budzi sumienia”, „Głos” 1903, nr 14, s. 214 [SK].

Miller A.: Jeden z „młodych” o Sienkiewiczu, „Głos” 1903, nr 13, s. 200 [AM].

NAŁKOWSKI W.: Geneza produkcji i chwały pana Sienkiewicza, „Głos” 1903, nr 43, s. 679-680 [WN1].

NAŁKOWSKI W.: Zbyteczny ból, „Głos” 1903, nr 13, s. 198-200 [WN2].

PRZYBYSZEWSKI S.: List otwarty do Henryka Sienkiewicza, „Głos” 1903, nr 13, s. 201 [SP1].

PRZYBYSZEWSKI S.: Przyczynek do psychologii biednego człowieka, „Głos” 1903, nr 17, s. 265-266 [SP2].

PRZYBYSZEWSKI S.: Smutny epilog smutnej sprawy, „Głos” 1903, nr 15, s. 232-233 [SP3]. 
W.O.: Protest kobiety, „Głos” 1903, nr 15, s. 232 [P].

WĘGLIŃSKI A.: Zbudźmy się!, „Głos” 1903, nr 18, s. 278-279 [AW].

Wszystkie numery pisma udostępniła Mazowiecka Biblioteka Cyfrowa, online:

http://mbc.cyfrowemazowsze.pl/dlibra/publication?id=19882\&from=\&dirids=1\&tab=1\&lp=1\&QI=

\author{
ETYCZNY ASPEKT WYPOWIEDZI \\ OCENIAJACYCH I WARTOŚCIUJĄCYCH \\ POŚWIECCONYCH SIENKIEWICZOWI I JEGO TWÓRCZOŚCI \\ (NA PODSTAWIE RECENZJI I TEKSTÓW POLEMICZNYCH \\ PUBLIKOWANYCH W „GEOSIE”)
}

S t r e s z c z e n i e

Artykuł zawiera analizę semantyczno-funkcjonalną nieetycznych zachowań językowych zawartych w recenzjach i innych artykułach polemicznych na temat Sienkiewicza i jego twórczości, publikowanych na łamach warszawskiego „Głosu”. W badaniach uwzględniono środki językowe systemowe oraz kontekstowe negatywne pod względem emocjonalnym i uczuciowym, których celem było zelżenie, wykpienie, ośmieszenie Sienkiewicza i/lub jego pisarstwa.

Słowa kluczowe: etyka słowa; leksyka; polemika prasowa; Sienkiewicz. ETHICAL ASPECT OF EVALUATIVE AND EVALUATIVE
STATEMENTS ABOUT THE TRILOGY AND SIENKIEWICZ
(BASED ON REVIEWS AND COLUMNS PUBLISHED IN "GŁOS")

\title{
S u m m a r y
}

The article contains a semantic and functional analysis of unethical language behaviors included in reviews and other polemical articles about Sienkiewicz and his work, published in the Warsaw's „Głos”. The studies take into account systemic and contextual linguistic means which are negative in terms of emotions and feelings, the aim of which was to insult, mock and ridicule Sienkiewicz and/or his writing.

Key words: ethics of words; lexis; press polemics; Sienkiewicz.

Translated by Aleksandra Mariak 